\title{
Contribution of Agriculture, Forestry, and Other Land Use to Climatic Phenomena Through GHG Emissions in Burundi. Empirical Evidence From the ARDL Approach
}

Aboyitungiye Jean Baptiste ( $\square$ aboyitu@gmail.com )

Universitas Sebelas Maret Fakultas Ekonomi https://orcid.org/0000-0002-6221-4982

\section{Suryanto Suryanto}

Sebelas Maret University Faculty of Economics and Business: Universitas Sebelas Maret Fakultas

Ekonomi dan Bisnis

\section{Evi Gravitiani}

Sebelas Maret University Faculty of Economics: Universitas Sebelas Maret Fakultas Ekonomi dan Bisnis Nindamutsa Arnaud

Burundi Institute of Agricultural Sciences: Institut des Sciences Agronomiques du Burundi

Ngezahayo Eric

Sebelas Maret University Postgraduate Studies: Universitas Sebelas Maret Pascasarjana

\section{Research}

Keywords: CO2 emissions, sustainable environment, agriculture, forestry, climatic phenomena

Posted Date: May 4th, 2021

DOI: https://doi.org/10.21203/rs.3.rs-421750/v1

License: (c) (i) This work is licensed under a Creative Commons Attribution 4.0 International License.

Read Full License 


\title{
Contribution of agriculture, forestry, and other land use to climatic phenomena through GHG emissions in Burundi. Empirical evidence from the ARDL approach
}

\author{
Aboyitungiye Jean Baptiste ${ }^{1 *}$, Suryanto ${ }^{1}$, Evi Gravitiani ${ }^{1}$, Nindamutsa Arnaud ${ }^{2}$, Ngezahayo Eric ${ }^{3}$ \\ 1 Department of Economic and Development Studies, Sebelas Maret University, \\ Jl Ir. Sutami 36 A Surakarta Jawa Tengah, Indonesia, \\ ${ }^{2}$ Department of Rural Development and Agribusiness, Burundi National University, \\ 54 Avenue de l'Universite \\ ${ }^{3}$ Departement of environmental sciences, Sebelas Maret University, \\ Jl Ir. Sutami 36 A Surakarta Jawa Tengah, Indonesia, \\ *Corresponding author: aboyitu@gmail.com
}

\begin{abstract}
In a world where we live in a climatic hazard disaster, understanding human activities' impact on the environment becomes crucial, especially for developing countries. This study addresses this issue through the prism of carbon dioxide emissions $\left(\mathrm{CO}_{2}\right)$ by examining how the growth of agricultural, forestry, and other land-use activities affects the environment. This study examines the long-term relationship between $\mathrm{CO}_{2}$ emissions and agriculture, forestry, and other land use by introducing other explanatory variables such as income per capita and population for 1970-2016. The econometric analysis results confirm a positive long-term relationship between $\mathrm{CO}_{2}$ emissions and agriculture, forestry, and other land use. The Granger causality tests show that this relationship's direction goes from agriculture, forestry, and other land use to $\mathrm{CO} 2$ emissions. For a developing country like Burundi, it is the growth of agricultural, forestry, and other land-use activities that determine GHG emissions level and not the other way around. Moreover, the ARDL model results adopted in this study validate our hypothesis, which assumes that Burundi has not yet reached its turning point in $\mathrm{CO} 2$ emissions due to economic growth. A low-carbon policy in favor of the
\end{abstract}


environment can be implemented, and this cannot risk any negative repercussions on economic growth.

Keywords: $\mathrm{CO} 2$ emissions, sustainable environment, agriculture, forestry, climatic phenomena 


\section{Introduction}

Over the centuries, humanity has constantly faced the rise in earth temperature challenges in the short and long term. Our society, which aims for efficiency, productivity, and optimization, has no more control than expected over the climate's impacts [1]. This efficient, productive, and optimized society can be significantly disrupted by natural climate variability. Nevertheless, this activity contributes to aggravate its vulnerability by adding massively to the atmosphere of greenhouse gases which have already started to disturb significantly a climate that has been in equilibrium for more than 10,000 years[2]. During these 10,000 years, the amount of GHGs present in our atmosphere was relatively constant and allowed the Earth to maintain a relatively stable climate (Figure 1). These gases' concentration began to rise with the advent of industrialization, increased demand for energy, population growth, and land-use changes [3].
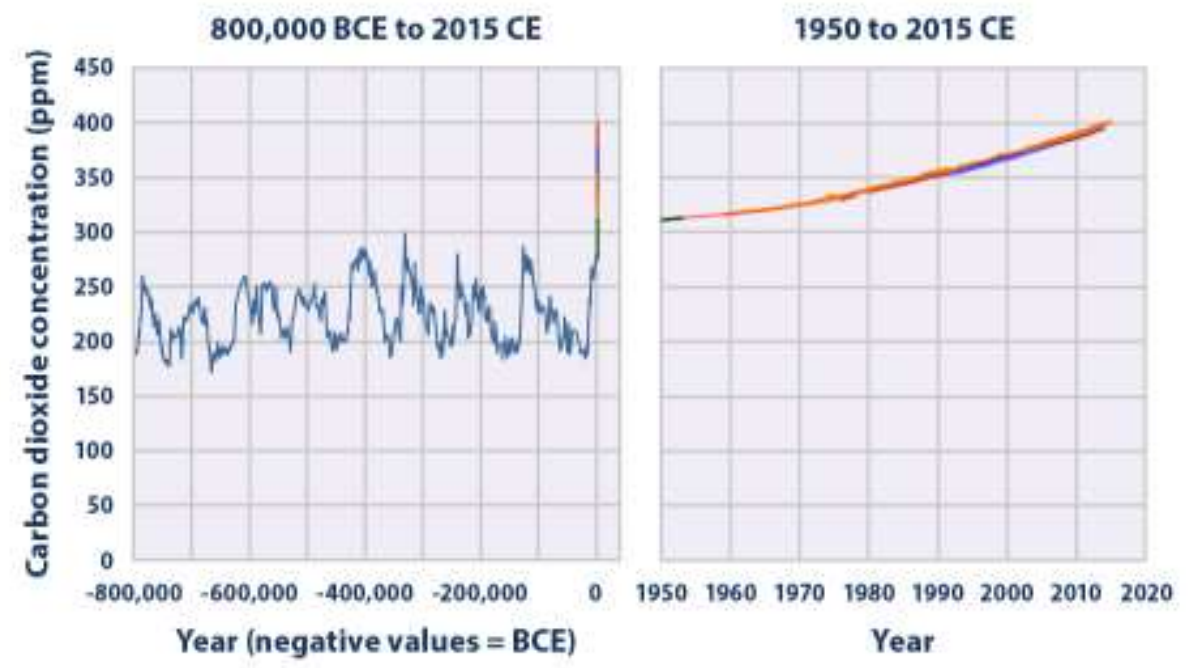

Figure 1: GHGs concentration over the century (EPA.Gov, 2020)

Scientists and researchers have confirmed human activities' role in these changes $[4,5,6]$. Humanity has increased its needs by continuing natural resources[7]. These activities' induced effects accentuate the natural greenhouse effect and raise the Earth's surface's average temperature [8]. The weather rose to a higher level in 2020 , about $14.9^{\circ} \mathrm{C}, 1.2^{\circ} \mathrm{C}$, above the pre-industrial (1850-1900) level (Figure 2). This phenomenon, known as global warming, affects rainfall and other atmospheric and climatic phenomena, 
endangering human, animal, and plant life due to the potentially catastrophic consequences of climate change $[9,10]$.

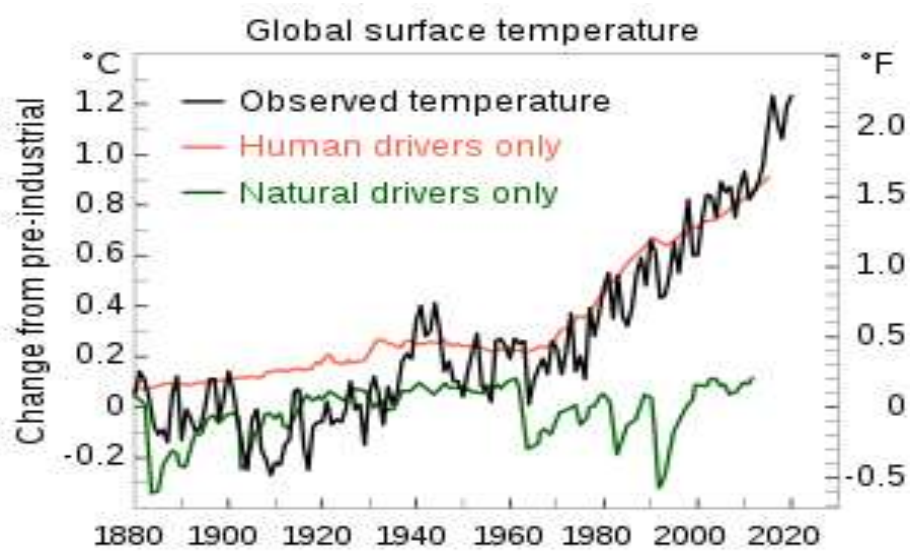

Figure2: Annual mean surface air temperature, NASA 2020

Preparations are being made to combat these inevitable effects, and new means are being explored to reduce the gas emissions that are the cause. Zhang and Dong [11] have affirmed that a cleaner green technology and changing consumer habits would reduce harmful emissions and stem global warming. It is too late to avoid some severe climate change incidents in some developing countries[12]. Known as the least developed continent globally, Africa appears to be one of the most vulnerable continents to climate change. However, it is less responsible for the ozone layer's degradation than other continents[13]. Besada and Werner[14] have demonstrated that a third of the continent's population already lives in areas of drought. Further, Connolly-Boutin and Smit [15]' research affirmed that an additional 75 to 250 million people could lose their livelihoods due to climate change by the end of the next decade.

One of the consequences that we think of first when we talk about Africa's global warming is the rise in sea levels, with its harmful effects on low-lying coastal areas (floods, vulnerability to storms)[16]. Climate changes such as rising temperatures, reduced water supplies, loss of biodiversity, and ecosystems' degradation have manifested agriculture effects. Current projections suggest that agricultural production's potential will decline in parts of Africa subject to severe climate crises[17]. Warming of around two degrees 
Celsius would lead to a $10 \%$ reduction in total crop yield in sub-Saharan Africa by 2050[18]. It will pose a new threat to the roughly $65 \%$ of African workers whose livelihoods depend on agriculture[19].

Agricultural activities, like other sectors, are the source of air pollutant emissions[Figure 3, [20]. The farm sector mainly contributes to releases of ammonia and greenhouse gases, which impact the climate[21]. The GHG emissions in Africa are caused by deforestation, soil impoverishment, and erosion, which, in addition to undermining traditional agriculture, releases significant amounts of carbon[22].

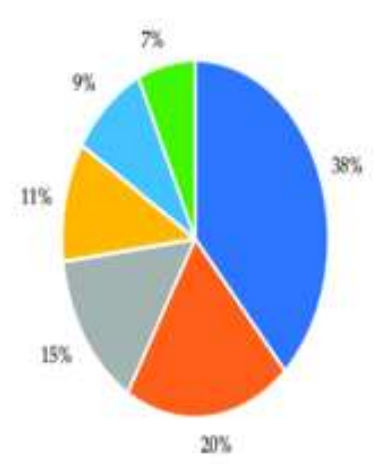

Imasiku et al., (2020)
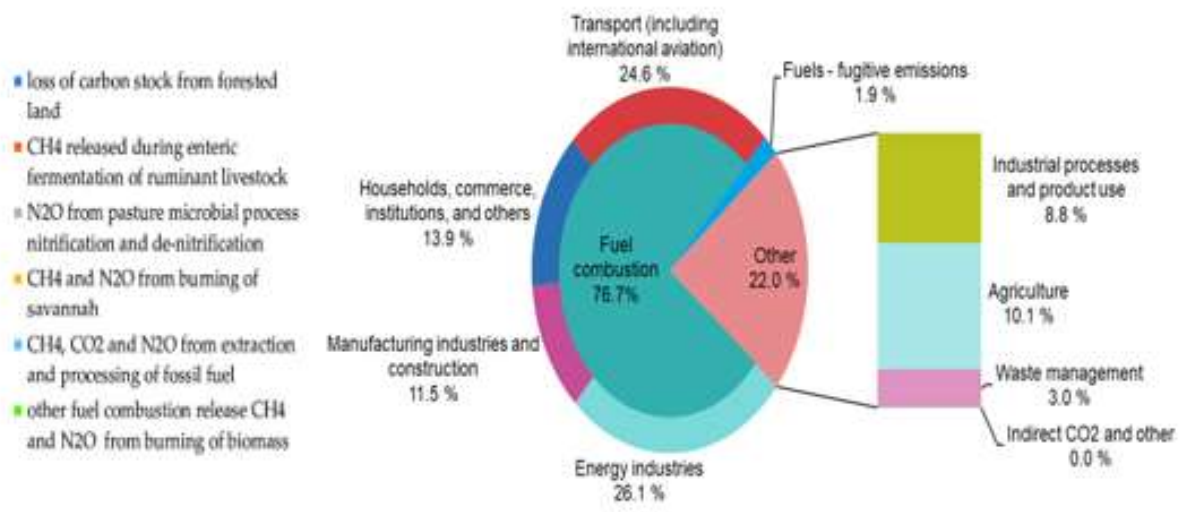

IPCC source sector GHG, The World

Figure 3: Greenhouse gas (GHG) emission sources GHG emission sources SSA

Reports and conferences have been made on the causes and impacts of climate change on this continent and various African countries' adaptation capacities[23]. The continent remains vulnerable to climatic variability because of its multiple political stresses it knew and its ability to respond that remains weak[24]. The Horn of Africa's arid coasts to East Africa's rainforests are among the most vulnerable of the continent, where rainfall is $200 \%$ or more than usual during the rainy season[25]. Heavy rains recorded have caused floods, landslides, and damage to infrastructure and livelihoods in Burundi, Kenya, Ethiopia, Rwanda, Somalia, and Tanzania. Burundi, the water levels of Lake Tanganyika are the highest since 1964(latawama.org). 


\subsection{A brief history of AFOLU in Burundi}

The relationship between agricultural practices and environmental conditions has raised great interest as long as it is the primary source of life for humans[26]. According to the data compiled by moody's analytics data, Burundi's agricultural sector employs more than $90 \%$ of the working population and contributes more than $40 \%$ of the GDP. It provides the country with more than $90 \%$ of foreign exchange earnings and provides $95 \%$ of food intake. Nevertheless, this sector is characterized by subsistence agriculture essentially dominated by food crops that occupy $90 \%$ of the land cultivated by about 1.2 million rural families, each less than one hectare of land and whose production is mainly self-consumed by households. Livestock, mainly of the extensive type, enter the gross domestic product for only $5 \%$ and continuously decline because of the decrease in grazing areas. The natural and artificial forests occupy about 200,000 hectares. They are devoted to protecting the land heritage against erosion, regulating hydrological systems, wildlife conservation, and the provision of firewood, construction, and timber.

\subsection{AFOLU and GHG emissions}

Taking agricultural practices in the greenhouse gas balance faces uncertainty sources. Pradhan and Limmeechokchai [27] reported that the GHG emission from Thailand agricultural sector in 2015 was estimated to be $45.3 \mathrm{MtCO}_{2} \mathrm{eq}$ and projected to reach $51.2 \mathrm{MtCO}_{2} \mathrm{eq}$ in 2030 and $63.6 \mathrm{MtCO}_{2} \mathrm{eq}$ in 2050 . These agricultural GHGs emissions originate from soil management, enteric fermentation, energy use, and manure management[28]. In descending order of magnitude, methane $\left(\mathrm{CH}_{4}\right)$, nitrous oxide $\left(\mathrm{N}_{2} \mathrm{O}\right)$, and carbon dioxide $\left(\mathrm{CO}_{2}\right)$ are the primary GHGs related to AFOLU[20]. Almaraz et al. [29] have shown that biogenic emissions of NOx from agricultural areas are much higher than we used to believe. Natural processes produce this gas, but its production is enhanced by the leaching, volatilization, and runoff of nitrogen fertilizers and the decomposition of crop residues and animal wastes[30]. In the Auvergne-RhôneAlpes region, in 2015, the agricultural sector was the source of primary fine particle emissions 6,100 tons, $37 \%$ of total particles in suspension, and $6 \%$ of carbon dioxide emissions of nitrogen NOx (Cadastre of Atmo -Auvergne-Rhône-Alpes emissions 2017 version). 
The investigation of HUANG et al.[31] on NH3 emissions from agriculture in Jiangsu Province, which used the emissions factor method, the $\mathrm{NH}_{3}$ emissions from agriculture were mainly contributed by livestock and nitrogen fertilizer application. Livestock produces about 40 percent of the world's gas emissions, mineral fertilizers 16 percent, and biomass combustion and crop residues about 18 percent [32, 33]. Ammonia is one of the leading causes of acid rain, which damages trees, acidifies soils, lakes, and rivers, and damages biodiversity [34]. Further, Xu et al. [35] have incorporated the Bi-NH3 module into the process-based Dynamic Land Ecosystem Model to estimate $\mathrm{NH}_{3}$ emission from agricultural systems in SA. The $\mathrm{NH}_{3}$ is expected to increase due to the increase in population needs.

YUE and GAO[36] have compared the global annual GHG emissions from natural systems with those generated by human activity. Humans were accounted for about 90 percent of biomass combustion, mostly from deliberately ignited forest fires as part of the clearing and burning of pastures. Nevertheless, burning biomass to clear land for agriculture is also a common practice that produces $\mathrm{CO} 2$ and other local pollutants[36].

According to Singh and Singh [38], traditional agriculture threatens the environment and releases nitrous oxide, phosphorus, and heavy metals into the atmosphere. The conversion of peatlands to fields, deforestation, fertilizers, cultivation, and animal husbandry produce large amounts of emissions that affect the climate. The expansion of agriculture and animal husbandry has been identified as one of the leading causes of emissions from deforestation[38]. In agriculture, deforestation is carried out directly by transforming forests into agricultural areas[39]. Once the forest cover is removed, GHG is released into the atmosphere, and lands are exposed to erosion, loss of minerals and nutrients[40].

Even though the increasingly recognized importance of emissions from agriculture, forestry, and other land uses in Africa in the global carbon cycle, there is a lack of empirical study on GHG emissions of this sector. Burundi carries a risk of hurting its environment by exhausting goods supplied by AFOLU if there is a causal link between environment degradation by GHG emissions and AFOLU. It is argued that AFOLU activities lead to $\mathrm{CO}_{2}$ emission sources primarily from agriculture[41]. 
This paper investigates, therefore, whether there is such a relationship in Burundi. A study on GHGs sources is vital for the definition of public policy instruments. If the links between emissions and sinks are crucial at a given geographic scale, an effective policy will likely cover all sources and sinks to limit unknown effects on the climate. In the case of Burundi, $\mathrm{CO}_{2}$ emissions are poorly documented. This article's contribution considers all the sources of agricultural emissions and the sources of $\mathrm{CO} 2$ linked to climatic phenomena.

\section{Econometric specifications and estimation methodology}

This paper follows the methodology of studies carried out on the relationships between human activities and environmental pollution, which goes through what has come to be called 'the EHRLICH equation:

$I=P A T$

Where, I: the total ecological impact, P: population, A: level of economic activity per capita (identified through production or consumption per capita), and $\mathrm{T}$ : the vector of observed variables representing technology, social organization, and other all factors affecting human impact on the environment other than population and affluence.

This equation assumes a formulation (EHRLICH) that retains elasticity values (ecological elasticities).

$I=a P^{b} A^{c} T^{d} e$

Where e, the random term (possibly including other explanatory variables); b, c, d the ecological elasticity values, respectively for $\mathrm{P}, \mathrm{A}$, and $\mathrm{T}$.

This model is tested according to a log-linear equation

$\ln I=a+b \ln p+c \ln A+d \ln T+e$ 
However, more recent work has given stochastic content to this equation, replacing $\mathrm{T}$ with a random term, allowing interesting statistical treatments. In addition to considering component $\mathrm{T}$ as an arbitrary term, it is possible to incorporate into the equation other variables supposed to explain the environmental impact.

By going through this modeling, our study attempts to clarify the factors responsible for environmental impacts (particularly $\mathrm{CO} 2$ emissions) by integrating AFOLU, population, and per capita income as explanatory variables to test the long-term relationship known as cointegration between $\mathrm{CO} 2$ emissions.

The following logarithmic form is proposed:

$L C O_{2 t}=\beta_{0}+\beta_{1} L(A F O L U)+\beta_{2} L(P O P)+\beta_{3} L(G D P C)+\varepsilon_{t}$

$\mathrm{CO}_{2}$ : carbon dioxide emissions estimated in kt, AFOLU: Agriculture, Forestry and others Land Use, POP: Population and GDPC: Income per habitant. Parameters $\beta_{0}, \beta_{1}, \beta_{2}$, and $\beta_{3}$ represent the long-term elasticity of $\mathrm{CO}_{2}$ emissions with L(AFOLU), L(POP), L(GDPC), respectively.

Cointegration suggests that a long-run equilibrium relationship links specific pairs of economic variables. While these variables may stray from equilibrium for some time, economic forces are expected to reset them. The most standard cointegration tests closely related to unit root tests have been proposed by Engle and Granger (1987). We should also mention the approach of Stock \& Watson (1988), as well as the multivariate method of Johansen (1988) and developed by Johansen (1991). We opted for a different approach which is that of ARDL (Autoregressive distributed lag model), also called black box, introduced by Pesaran and Shin (1999) then developed by Pesaran, Shin, and Smith (2001). The ARDL modeling with the appropriate offsets will correct problems of correlation and endogeneity of the series. Another reason for using the ARDL approach is that it is more robust and performs better for small sample sizes than other cointegration techniques. 
Our model Equation is transformed as follows:

$\Delta L C O 2_{t}=\beta_{0}+\sum_{i=1}^{p} \delta_{i} \Delta L(C O 2)_{t-1}+\sum_{i=1}^{p} \gamma_{i} \Delta L(A F O L U)_{t-1}+\sum_{i=1}^{p} \omega_{i} \Delta L(P O P)_{t-1}+$ $\sum_{i=1}^{p} \varphi_{i} \Delta L(G D P C)_{t-1}+\rho_{1} L(C O 2)_{t-1}+\rho_{2} \Delta L(A F O L U)_{t-1}+\rho_{3} L(P O P)_{t-1}+\rho_{4} L(G D P C)_{t-1}+U_{t}$

Where, $\beta_{0}$ is the drift component, and $U_{t}$ the white noise. The terms with the summation signs represent the error correction model, while those with the $\rho_{t}$ the coefficient represents the long-term relationship. The verification of the cointegration relation is carried out on the Bounds Test. It consists of carrying out an F-test on the hypothesis $\rho_{1}=\rho_{2}=\rho_{3}=\rho_{4}=0$ against the alternative hypothesis $\rho_{1} \neq \rho_{2} \neq \rho_{3} \neq$ $\rho_{4} \neq 0$.

To choose an optimal delay for each variable, the ARDL method estimates $(p+1)^{k}$ regressions where $\mathrm{p}$ is the maximum number of lags and $\mathrm{k}$ the number of variables in the equation. The model can be chosen based on the Schwarz-Bayesian criteria (SBC) and the Akaike information criteria (AIC). The error correction model can then be estimated:

$\Delta L C O 2_{t}=\beta_{0}+\sum_{i=1}^{p} \delta_{i} \Delta L(C O 2)_{t-1}+\sum_{i=1}^{p} \gamma_{i} \Delta L(A F O L U)_{t-1}+\sum_{i=1}^{p} \omega_{i} \Delta L(P O P)_{t-1}+$

$\sum_{i=1}^{p} \varphi_{i} \Delta L(G D P C)_{t-1}+\mu E C M_{t-1}+U_{t}$

The data used in this study are taken from the World Development Indicators database of the World Bank

\section{Empirical Results and Discussion}

This study uses the Augmented Dickey-Fuller (ADF) and Phillips Perron (PP) stationarity tests to determine the series's integration order. Beforehand, it is necessary to ensure that no string is integrated of order two because the critical values provided by Pesaran et al.(2001) only concern integration levels of 0 and 1 . The results of these tests are reported in Table 1 . They indicate that all series are not stationary in level but stationary in the first difference. They are therefore integrated of order 1. AIC, SC, LR, and HQ criteria are 
then used to select the optimal delay number of the vector autoregressive (VAR). The AIC criterion implies a delay of 5, while the LR, SC, and HQ criteria imply an uncertainty of 2 . It is this last criterion that is retained for this study.

Table 1: Unit root tests on variables

At level

\begin{tabular}{lcccccc}
\hline \multicolumn{5}{c}{ Augmented Dicky Fuller (ADF) } & \multicolumn{3}{c}{ Philips Perron (PP) } \\
\hline & $(\mathbf{1})$ & $\mathbf{( 2 )}$ & $\mathbf{( 3 )}$ & $\mathbf{( 1 )}$ & $\mathbf{( 2 )}$ & $\mathbf{( 3 )}$ \\
\hline LCO $_{2}$ & -1.37 & -1.94 & 1.85 & -1.30 & -1.92 & -2.12 \\
\hline LAFOLU & -1.71 & -1.62 & 2.28 & -1.71 & -1.74 & -1.94 \\
\hline LGDPC & -2.009 & -1.71 & 1.95 & -2.01 & -1.89 & 1.29 \\
\hline LPOP & -2.45 & -2.82 & 0.02 & -1.54 & -2.001 & 0.02 \\
\hline
\end{tabular}

\section{At first difference}

\begin{tabular}{lllllll}
\hline DLCO $_{2}$ & $-8.23 *$ & $-8.13 *$ & $-7.59 *$ & $-8.09 *$ & $-8.02 *$ & $-7.54 *$ \\
\hline DLAFOLU & $-5.34 *$ & $-5.34 *$ & $-4.94 *$ & $-5.32 *$ & $-5.32 *$ & $-4.94^{*}$ \\
\hline DFLGDPC & $-4.86^{*}$ & $-4.91 *$ & $-2.36^{*}$ & $-4.97 *$ & $-5.02 *$ & $-4.68^{*}$ \\
\hline DLPOP & -2.39 & $-2.36 * *$ & $-2.35 *$ & $-2.97 *$ & $-2.91 * *$ & $-2.92 *$
\end{tabular}

Notes: $(* *)$ Significant at the $1 \% ;(*)$ Significant at the $5 \%$

MacKinnon (1996) one-sided p-values.

(1): model with constant

(2): model with constant and trend

(3): model without constant and trend.

The ADF and PP tests have the null hypothesis of the presence of a unit root. The number of delays is automatically selected according to the criteria of Schwarz Info.

Table 2: VAR Lag Order Selection Criteria

\begin{tabular}{lllllll}
\hline Lag & LoL & LR & FPE & AIC & SC & HQ \\
\hline $\mathbf{0}$ & -1.94 & - & 1.58 & 0.28 & 0.44 & 0.34 \\
\hline $\mathbf{1}$ & 151.35 & 270.11 & 2.28 & -6.25 & -5.42 & -5.95 \\
\hline
\end{tabular}




\begin{tabular}{lllllll}
\hline $\mathbf{2}$ & 214.82 & 99.72 & 2.43 & -8.51 & $-7.02^{*}$ & -7.96 \\
\hline $\mathbf{3}$ & 240.69 & 35.73 & 1.61 & 8.98 & -6.83 & -8.19 \\
\hline $\mathbf{4}$ & 265.03 & $28.97 *$ & $1.21^{*}$ & 9.38 & -6.57 & $-8.35^{*}$ \\
\hline $\mathbf{5}$ & 281.47 & 16.44 & 1.45 & $-9.40^{*}$ & -5.93 & -8.12 \\
\hline
\end{tabular}

* indicates lag order selected by the criterion

LR: sequential modified LR test statistic (each test at 5\% level)

FPE: Final prediction error

AIC: Akaike information criterion

SC: Schwarz information criterion

HQ: Hannan-Quinn information criterion

To determine the long-term relationship between variables, we use ARDL or Black Box approach for cointegration. For this, the Bound Test is used, which calculates an F-statistic (Table 3). It tests the null hypothesis that the lagged variables' coefficients in equation (4) are zero. The F-statistic is equal to 6.843977 compared to the critical values below and above the threshold significance of $5 \%$ and $1 \%$. The test statistic is above the upper limit (4.35 and 5.61, respectively). Therefore, we reject the null hypothesis of the absence of cointegration. We conclude the existence of a long-term relationship between the model's variables. The Granger causality test is performed on the variables to determine this relationship's direction (Table 4).

Table 3: ARDL Bounds Test

\section{F-statistic $\quad 6.843977$}

\begin{tabular}{lll}
\hline & \multicolumn{2}{c}{ Critical Value Bounds } \\
\hline Significance & $\mathrm{I}(0)$ Bound & I(1) Bound \\
\hline $\mathbf{5 \%}$ & 3.23 & $\mathbf{4 . 3 5}$ \\
\hline $\mathbf{1 \%}$ & 4.29 & $\mathbf{5 . 6 1}$ \\
\hline
\end{tabular}


The Granger causality test (Table 4) shows a causal relationship between the two main variables of interest (AFOLU and $\mathrm{CO}_{2}$ ) and that this relationship is in the direction of AFOLU towards $\mathrm{CO}_{2}$ emissions. In other senses, agriculture, forestry, and other land-use granger cause $\mathrm{CO}_{2} \mathrm{emissions}$ but not vice-versa. The same result is also valid for the GDPC and POP variables; the evolution of $\mathrm{CO} 2$ emissions depends on GDP per capita and POP. A low-carbon policy in favor of the environment can be implemented, and this cannot risk any negative repercussions on economic growth.

Table 4: Granger causality test

\begin{tabular}{lcc}
\hline Null Hypothesis & F-Statistic & P-Value \\
\hline LAFOLU does not Granger Cause LCO2 & 8.93368 & 0.0006 \\
\hline LCO2 does not Granger Cause LAFOLU & 0.85677 & 0.4322 \\
\hline LGDPC does not Granger Cause LCO2 & 6.06749 & 0.0050 \\
\hline LCO2 does not Granger Cause LGDPC & 1.15319 & 0.3259 \\
\hline LPOP does not Granger Cause LCO2 & 2.76873 & 0.0748 \\
\hline LCO2 does not Granger Cause LPOP & 0.73537 & 0.4857 \\
\hline
\end{tabular}

Note: *indicates a significative level at 5\%

Table 5: ARDL estimations (Long-run)

\begin{tabular}{|c|c|c|c|c|}
\hline \multicolumn{5}{|c|}{ Dependent Variable: LCO2 } \\
\hline \multicolumn{3}{|c|}{ Independent variables Coefficients } & Std. Error T-Statistic & \multirow{2}{*}{$\begin{array}{l}\text { Prob.* } \\
0.0000\end{array}$} \\
\hline LAFOLU & 2.037336 & 0.214254 & 9.508992 & \\
\hline LGDPC & -1.102593 & 0.257440 & -4.282918 & 0.0039 \\
\hline LPOP & -0.157243 & 0.051167 & -3.073155 & 0.0039 \\
\hline $\mathbf{C}$ & -29.247872 & 3.086304 & -9.476667 & 0.0000 \\
\hline $\mathbf{R}^{2}$ & 0.94 & & justed & 0.937096 \\
\hline F-Statistic & 110.2 & & n-Watson stat & 2.448944 \\
\hline
\end{tabular}

Note: *ARDL $(1,2,0,0)$ selected based on Schwarz criterion (SIC) 
The coefficient signs of LGDPC and LPOP variables are negative and significant(Table 5). Their coefficients (--1.102593 and -0.157243) suggest that the contribution of income per capita and population to $\mathrm{CO} 2$ emissions is minimal. On the other hand, the adjustment parameters $\mathrm{R}^{2}$ and $\mathrm{R}^{2}$ adjusted are equal to 0.945674 and 0.937096 , respectively. The model is well fitted.

The error correction model (ECM) mechanism is used to test the short-run relationship between variables (Table 6). The results show that the error-corrected term ECM(-1) coefficient is significant, which implies that the speed of short-run adjustment to reach equilibrium is substantial. On the other hand, this term equals -0.689295 suggests that when $\mathrm{CO} 2$ emissions are above or below their equilibrium value, they would be adjusted by $68 \%$ per year. The coefficients of the lagged variables represent the short-run elasticities. Furthermore, a $1 \%$ increase in agriculture, forestry, and other land use would imply a $0.79 \%$ increase in $\mathrm{CO} 2$ emissions in the short term.

Table 6: ECM estimation (short -run)

\begin{tabular}{|c|c|c|c|c|}
\hline \multicolumn{5}{|c|}{ Dependent Variable: LCO2 } \\
\hline Independent variables & Coefficients & Std. Error & T-Statistic & Prob.* \\
\hline D(LAFOLU) & 0.792141 & 0.257836 & 3.072270 & 0.0039 \\
\hline D(LAFOLU(-1)) & -0.424403 & 0.209390 & -2.026857 & 0.0497 \\
\hline D(LGDPC) & -0.760012 & 0.260034 & -2.922739 & 0.0058 \\
\hline D(LPOP) & -0.108387 & 0.038933 & -2.783964 & 0.0083 \\
\hline ECM(-1) & -0.689295 & 0.136786 & -5.039216 & 0.0000 \\
\hline F-Statistic & 110.2465 & \multicolumn{2}{|c|}{ Durbin-Watson stat } & 2.448944 \\
\hline
\end{tabular}

Note: *ARDL $(1,2,0,0)$ selected based on Schwarz criterion (SIC)

We carried out diagnostic tests on residuals of the ARDL regression (Table 7). The White test confirms the absence of the residuals' heteroskedasticity, while the Jarque- Bera test shows that they follow a normal 
distribution. On the other hand, Ramsey's test shows no missing variables or functional form issues in the model.

Table 7: Residual diagnostic tests

\begin{tabular}{|c|c|c|c|}
\hline \multicolumn{4}{|c|}{ Heteroskedasticity Test: Breusch-Pagan-Godfrey } \\
\hline \multicolumn{4}{|c|}{ Null hypothesis: Absence of heteroskedasticity } \\
\hline F-statistic & 0.507476 & Prob. $\mathrm{F}(6,38)$ & 0.7988 \\
\hline Obs*R squared & 3.338260 & Prob. Chi-Square(6) & 0.7653 \\
\hline Scaled explained SS & 1.798913 & Prob. Chi-Square(6) & 0.9372 \\
\hline \multicolumn{4}{|l|}{ Ramsey RESET Test } \\
\hline \multicolumn{4}{|c|}{ Null hypothesis: The model is correctly specified } \\
\hline T-statistic & 0.021647 & Prob. & 0.9828 \\
\hline F-statistic & 0.000469 & Prob. & 0.9828 \\
\hline \multicolumn{4}{|l|}{ Normality test } \\
\hline \multicolumn{4}{|c|}{ Null hypothesis: Normal distributed } \\
\hline Jarque Bera & 1.063583 & P-Value. & 0.587551 \\
\hline
\end{tabular}

The last step in the ARDL or Black Box estimation is to check the stability of long and short-term parameters. CUSUM techniques based on the cumulative sum of recursive residuals and CUSUMQ based on the squared recursive residuals' cumulative sum are applied (Figure 4). The results show that the statistics graph of CUSUM and CUSUMQ remains within the interval of the critical values at the 5\% threshold, which implies that the model coefficients are stable. 

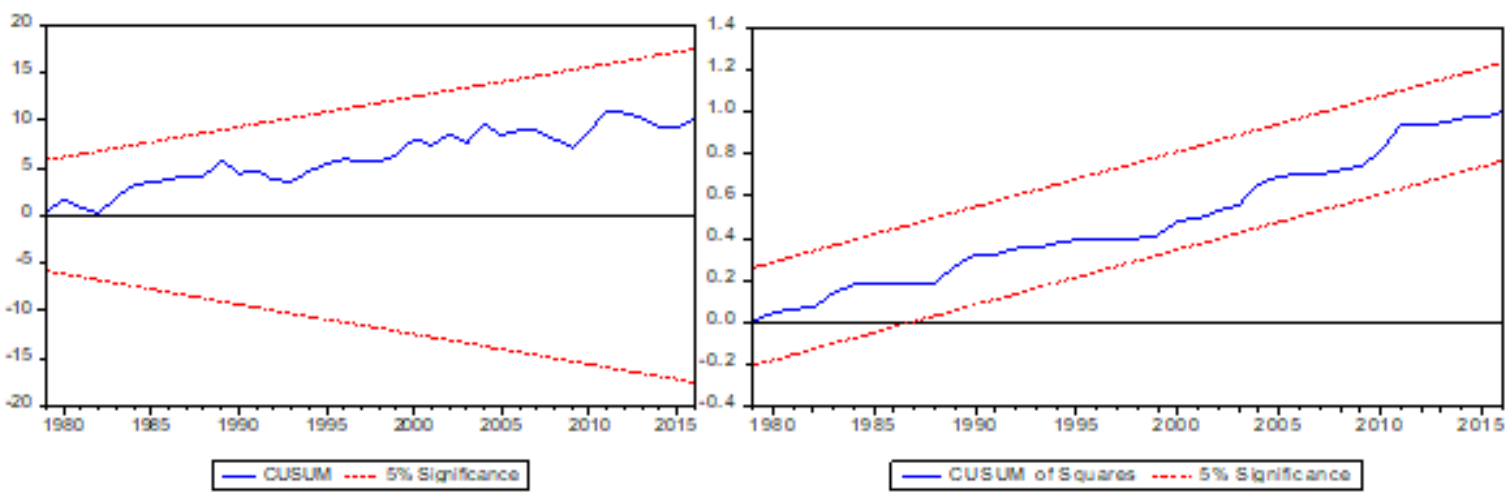

Figure 4: Stability test: COSUM AND COSUMQ

\section{Conclusion}

This study highlights carbon dioxide emissions trends by assessing how agriculture, forestry, and other land use growth affect the environment by analyzing the STIRPAT model's validity. We also integrate the income per capita and population as explanatory variables for the 1970-2016 period. The model assumptions were invested using the ARDL (Black Box) methodology and considering $\mathrm{CO}_{2}$ emissions to indicate environmental conditions.

It is based on recent advances in econometric research in the study of stationary time series, which allowed the development of a new methodology around the fundamental concepts of the ARDL model. It becomes easy, using this model, for the authorities to establish scenarios on the shortand long-term trends of $\mathrm{CO}_{2}$ emissions by focusing on economic, political, and demographic imperatives.

Empirical results confirm the presence of a robust long-term relationship between $\mathrm{CO}_{2}$ emissions and agriculture, forestry, and other land use (AFOLU). Furthermore, the positive sign of its coefficient and the negative sign of the constant valid the model for Burundi's case. 
However, it is not easy to confirm the share of the various $\mathrm{CO}_{2}$ emissions in the country since Burundi is among developing countries not considered atmospheric pollutants. Only actual observations of future values of $\mathrm{CO}_{2}$ emissions could categorically confirm these trends.

The long-run relationship estimation shows that a $1 \%$ increase in agriculture, forestry, and other land use would lead to a $2.03 \%$ increase $\mathrm{CO}_{2}$ emissions. Any increase in real GDP and population does not yet intensify excessive pollutants to cause an increase in $\mathrm{CO}_{2}$ emissions in the country. The Granger causality test indicates unidirectional causality from the income per capita and population to the $\mathrm{CO} 2$ emissions. Environmental policies towards sustainable development will not risk negative repercussions on a country's economic growth.

The CUSUM and CUSUMQ techniques show that the coefficients of the cointegrated ECM model are stable. The results also indicate that agriculture, forestry, and other land use remain significant determinants of $\mathrm{CO} 2$ emissions in the short run and the income per capita and population. However, their coefficients are negative, also remain substantial determinants.

In Burundi, populations, as well as the government, wish to develop protected areas. Nevertheless, this is not enough. In rural areas, people engage in systematic plundering of natural resources. Consequences are manifested by runoff to urban areas, and the health of Tanganyika Lake is soiled by pollution.

These results are encouraging, given that Burundi has a $\mathrm{REDD}^{+}$program to reduce greenhouse gas emissions linked to deforestation and forest degradation. Projects to support local communities in reforestation and sustainable agriculture could be established by involving local populations in the ecosystem's preservation and resource exploitation.

\section{Availability of data and materials}


The datasets of AFOLU analyzed during the current study are not publicly available due the sharing permission not approved by the Burundian Institute for Statistics and Economic Studies (BISES) but are available from the corresponding author on reasonable request and with permission of BISES.

\section{Competing interest}

No conflict of interest

\section{Funding}

Not applicable

\section{Author's Contribution}

Jean Baptiste and Eric helped with topic conceptualization and writing the initial draft. Suryanto and Evi Gravitiani consult the operational research and data interpretation. Nindamutsa Arnaud was based in Burundi to verify data from the world bank and the Burundian Institute of Statistics and Economic Studies. All authors contributed to the research implementation, discussion of results, and both approve for manuscript publication.

\section{Acknowledgment}

The authors wish to thank the Burundian Institute for Statistics and Economic Studies for the assistance provided during data collection. All comments and views are for authors.

\section{Reference}

[1] P. K. Rao, "The economics of global climatic change," Econ. Glob. Clim. Chang., pp. 1-201, 2016, doi: $10.4324 / 9781315501499$.

[2] R. Connolly, M. Connolly, R. M. Carter, and W. Soon, "How much human-caused global warming should we expect with business-as-usual (BaU) climate policies? A semi-empirical assessment," Energies, vol. 16, no. 3, 2020, doi: 10.3390/en13061365.

[3] C. A. Mgbemene, C. C. Nnaji, and C. Nwozor, "Industrialization and its backlash: Focus on climate change and its consequences," J. Environ. Sci. Technol., vol. 9, no. 4, pp. 301-316, 2016, 
doi: 10.3923/jest.2016.301.316.

[4] W. J. Ripple, C. Wolf, T. M. Newsome, P. Barnard, and W. R. Moomaw, "World Scientists' Warning of a Climate Emergency," 2019.

[5] S. M. Papalexiou, A. AghaKouchak, K. E. Trenberth, and E. Foufoula-Georgiou, "Global, Regional, and Megacity Trends in the Highest Temperature of the Year: Diagnostics and Evidence for Accelerating Trends," Earth's Futur., vol. 6, no. 1, pp. 71-79, 2018, doi: 10.1002/2017EF000709.

[6] A. Cendrero, L. M. Forte, J. Remondo, and J. A. Cuesta-Albertos, "Anthropocene Geomorphic Change. Climate or Human Activities?," Earth's Futur., vol. 8, no. 5, 2020, doi: 10.1029/2019EF001305.

[7] K. Swing, "The globalized thought process in relation to natural resources," An. Acad. Bras. Cienc., vol. 91, pp. 1-11, 2019, doi: 10.1590/0001-3765201920190236.

[8] X. L. YUE and Q. X. GAO, "Contributions of natural systems and human activity to greenhouse gas emissions," Adv. Clim. Chang. Res., vol. 9, no. 4, pp. 243-252, 2018, doi: 10.1016/j.accre.2018.12.003.

[9] A. D. King, "The drivers of nonlinear local temperature change under global warming," Environ. Res. Lett., vol. 14, no. 6, 2019, doi: 10.1088/1748-9326/ab1976.

[10] N. Saklani and A. Khurana, "Global Warming: Effect on Living Organisms, Causes and its Solutions," Int. J. Eng. Manag. Res., vol. 09, no. 05, pp. 24-26, 2019, doi: 10.31033/ijemr.9.5.4.

[11] X. Zhang and F. Dong, "Why do consumers make green purchase decisions? Insights from a systematic review," Int. J. Environ. Res. Public Health, vol. 17, no. 18, pp. 1-25, 2020, doi: 10.3390/ijerph17186607.

[12] F. T. Princiotta, "We are losing the climate change mitigation challenge; Is it too late to recover?," MRS Energy Sustain., vol. 4, no. 1, pp. 1-14, 2017, doi: 10.1557/mre.2017.5.

[13] World Meteorological Organiation, State of the Climate in Africa 2019, no. 1253. 2019.

[14] H. Besada and K. Werner, "An assessment of the effects of Africa's water crisis on food security 
and management," Int. J. Water Resour. Dev., vol. 31, no. 1, pp. 120-133, 2015, doi:

10.1080/07900627.2014.905124.

[15] L. Connolly-Boutin and B. Smit, "Climate change, food security, and livelihoods in sub-Saharan Africa," Reg. Environ. Chang., vol. 16, no. 2, pp. 385-399, 2016, doi: 10.1007/s10113-015-0761-

$\mathrm{x}$.

[16] E. Nyadzi, E. Bessah, and G. Kranjac-Berisavljevic, "Taking Stock of Climate Change Induced Sea Level Rise across the West African Coast," Environ. Claims J., vol. 33, no. 1, pp. 77-90, 2020, doi: 10.1080/10406026.2020.1847873.

[17] O. Serdeczny et al., "Climate change impacts in Sub-Saharan Africa: from physical changes to their social repercussions," Reg. Environ. Chang., vol. 17, no. 6, pp. 1585-1600, 2017, doi: 10.1007/s10113-015-0910-2.

[18] B. Sultan, D. Defrance, and T. Iizumi, "Evidence of crop production losses in West Africa due to historical global warming in two crop models," Sci. Rep., no. August, pp. 1-15, 2019, doi: 10.1038/s41598-019-49167-0.

[19] L. P. Id, C. Bourgoin, A. Martinez-valle, and P. La, "Vulnerability of the agricultural sector to climate change : The development of a pan- tropical Climate Risk Vulnerability Assessment to inform sub-national decision making," pp. 1-25, 2019.

[20] H. M. Naser, O. Nagata, S. Sultana, and R. Hatano, "Carbon sequestration and contribution of $\mathrm{CO} 2, \mathrm{CH} 4$ and $\mathrm{N} 2 \mathrm{O}$ fluxes to global warming potential from paddy-fallow fields on mineral soil beneath peat in Central Hokkaido, Japan," Agric., vol. 10, no. 1, pp. 1-18, 2020, doi: 10.3390/agriculture10010006.

[21] A. Balafoutis et al., "Precision Agriculture Technologies Positively Contributing to GHG Emissions Mitigation, Farm Productivity and Economics," pp. 1-28, doi: 10.3390/su9081339.

[22] S. S. Africa and C. Mbow, "Use It Sustainably or Lose It! The Land Stakes in," pp. 1-19, 2020.

[23] K. Imasiku, V. M. Thomas, and E. Ntagwirumugara, "Unpacking ecological stress from economic activities for sustainability and resource optimization in Sub-Saharan Africa," Sustain., vol. 12, no. 
9, pp. 1-12, 2020, doi: 10.3390/SU12093538.

[24] M. Okpara, A. State, and N. C. Tamale, "Climate Change in Sub-Saharan Africa: A menace to Agricultural productivity and Ecological protection," vol. 23, no. February, pp. 329-335, 2019.

[25] K. Borhara, B. Pokharel, B. Bean, L. Deng, and S. S. Wang, "and Future Projection," pp. 7-9, 2020.

[26] K. Pawlak and M. Kołodziejczak, "The role of agriculture in ensuring food security in developing countries: Considerations in the context of the problem of sustainable food production," Sustain., vol. 12 , no. 13 , 2020, doi: 10.3390/su12135488.

[27] B. B. Pradhan, A. Chaichaloempreecha, and B. Limmeechokchai, "GHG mitigation in Agriculture, Forestry and Other Land Use (AFOLU) sector in Thailand," Carbon Balance Manag., vol. 14, no. 1, pp. 1-17, 2019, doi: 10.1186/s13021-019-0119-7.

[28] E. Wójcik-Gront, "Analysis of sources and trends in agricultural GHG emissions from annex I countries," Atmosphere (Basel)., vol. 11, no. 4, 2020, doi: 10.3390/ATMOS11040392.

[29] M. Almaraz et al., "Erratum: Agriculture is a major source of NOx pollution in California (Science Advances DOI: 10.1126/sciadv.aao3477)," Sci. Adv., vol. 4, no. 6, pp. 1-9, 2018, doi: 10.1126/SCIADV.AAU2561.

[30] C. Oertel, J. Matschullat, K. Zurba, F. Zimmermann, and S. Erasmi, “Greenhouse gas emissions from soils-A review," Chemie der Erde, vol. 76, no. 3, pp. 327-352, 2016, doi: 10.1016/j.chemer.2016.04.002.

[31] J. HUANG, R. XIONG, L. FANG, T. LI, and W. SHEN, "Estimation of interannual trends of ammonia emissions from agriculture in Jiangsu Province from 2000 to 2017," Atmos. Ocean. Sci. Lett., vol. 13, no. 3, pp. 268-273, 2020, doi: 10.1080/16742834.2020.1736499.

[32] M. Hassouna et al., Measuring emissions from livestock farming : greenhouse gases, ammonia and nitrogen oxides To cite this version: HAL Id : hal-01567208. 2017.

[33] A. Anca-Couce, P. Sommersacher, N. Evic, R. Mehrabian, and R. Scharler, "Experiments and modelling of NOx precursors release (NH3 and $\mathrm{HCN})$ in fixed-bed biomass combustion 
conditions," Fuel, vol. 222, no. February 2018, pp. 529-537, 2018, doi:

10.1016/j.fuel.2018.03.003.

[34] P. Grennfelt, A. Engleryd, M. Forsius, Ø. Hov, H. Rodhe, and E. Cowling, "Acid rain and air pollution: 50 years of progress in environmental science and policy," Ambio, vol. 49, no. 4, pp. 849-864, 2020, doi: 10.1007/s13280-019-01244-4.

[35] R. T. Xu et al., "Half-Century Ammonia Emissions From Agricultural Systems in Southern Asia: Magnitude, Spatiotemporal Patterns, and Implications for Human Health," GeoHealth, vol. 2, no. 1, pp. 40-53, 2018, doi: 10.1002/2017GH000098.

[36] N. Santiago-De La Rosa et al., "Emission factors of atmospheric and climatic pollutants from crop residues burning," J. Air Waste Manag. Assoc., vol. 68, no. 8, pp. 849-865, 2018, doi: 10.1080/10962247.2018.1459326.

[37] R. Singh and G. S. Singh, "Traditional agriculture: a climate-smart approach for sustainable food production," Energy, Ecol. Environ., vol. 2, no. 5, pp. 296-316, 2017, doi: 10.1007/s40974-0170074-7.

[38] F. Pendrill et al., "Agricultural and forestry trade drives large share of tropical deforestation emissions," Glob. Environ. Chang., vol. 56, no. December 2018, pp. 1-10, 2019, doi: 10.1016/j.gloenvcha.2019.03.002.

[39] N. Doggart et al., "Agriculture is the main driver of deforestation in Tanzania," Environ. Res. Lett., vol. 15, no. 3, 2020, doi: 10.1088/1748-9326/ab6b35.

[40] L. J. R. Nunes, C. I. R. Meireles, C. J. P. Gomes, and N. M. C. A. Ribeiro, "Forest management and climate change mitigation: A review on carbon cycle flow models for the sustainability of resources," Sustain., vol. 11, no. 19, 2019, doi: 10.3390/su11195276.

[41] S. Ngarize, "AGRICULTURE FORESTRY AND OTHER LAND USE ( AFOLU )," no. March, 2016. 
Figures

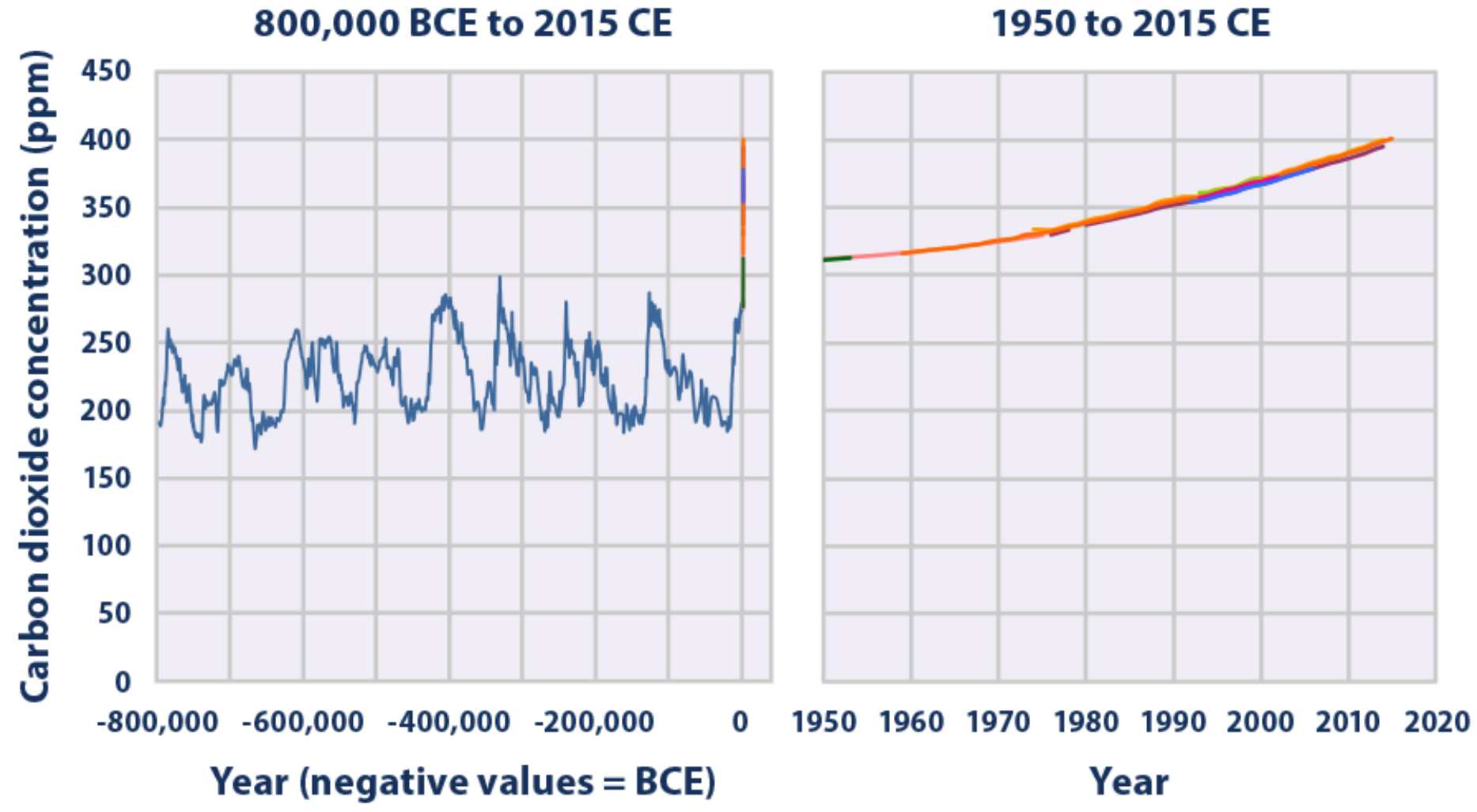

Figure 1

GHGs concentration over the century (EPA.Gov, 2020)

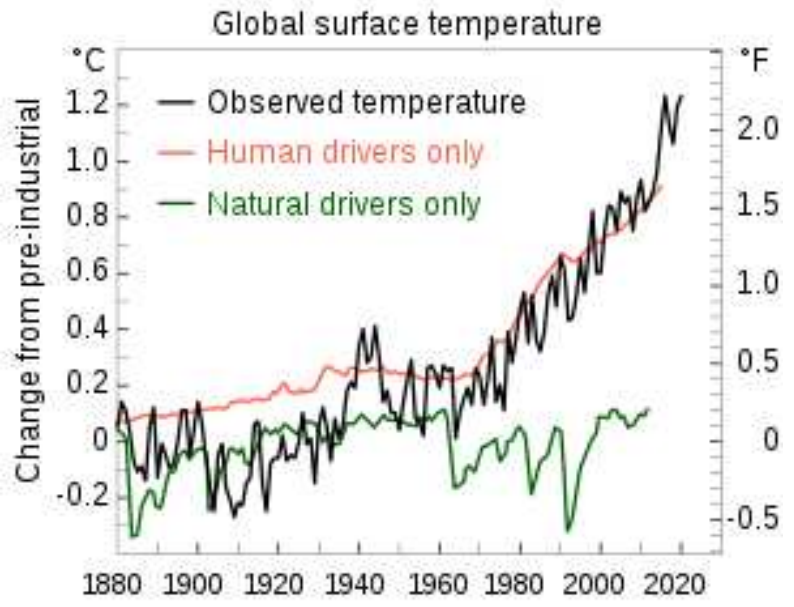

Figure 2

Annual mean surface air temperature, NASA 2020 


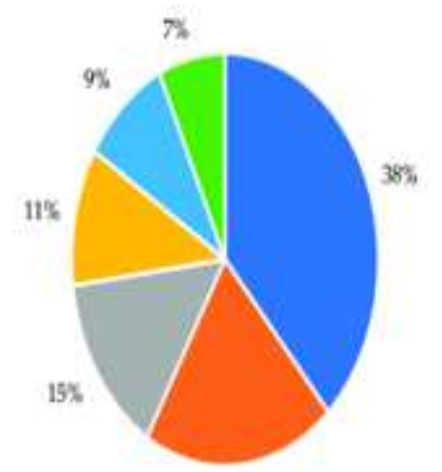

$20 \%$
- loss of carbon staxa from forested land

- CH4 relessed duting enteric fermentation of ruminunt livestock

- N2O froen pasture microbial process nitrification and de-nitrification

- $\mathrm{CH} 4$ and $\mathrm{N} 2 \mathrm{O}$ trum buming of swannath

- $\mathrm{CH} 4 \mathrm{CO}$ and $\mathrm{N} 2 \mathrm{O}$ trom extraction and proossing of fusst thet

n other fuel combustion reiesse CHA and $\mathrm{N} 2 \mathrm{O}$ from burning of biomass

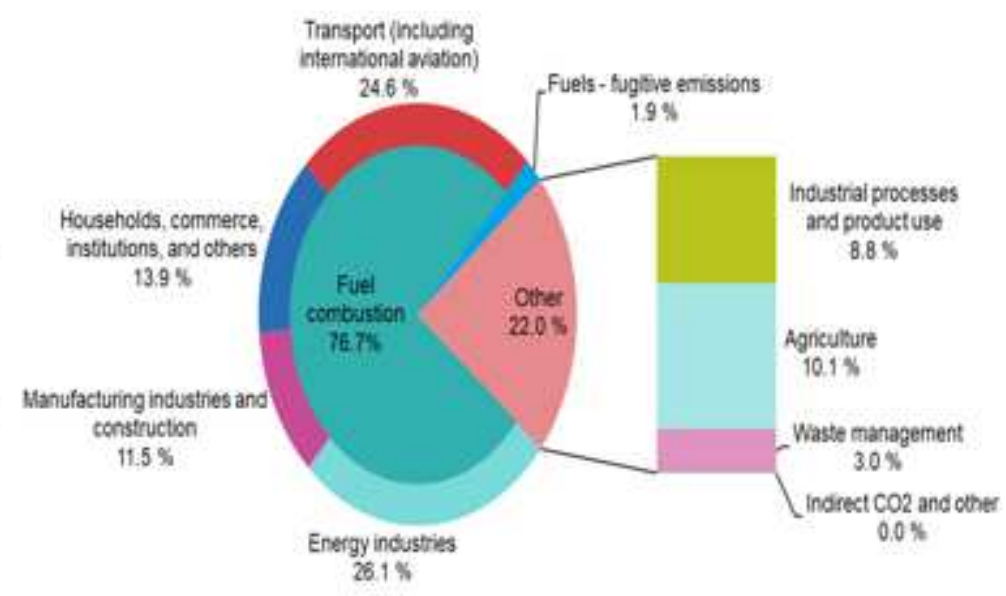

Figure 3

Greenhouse gas (GHG) emission sources GHG emission sources SSA
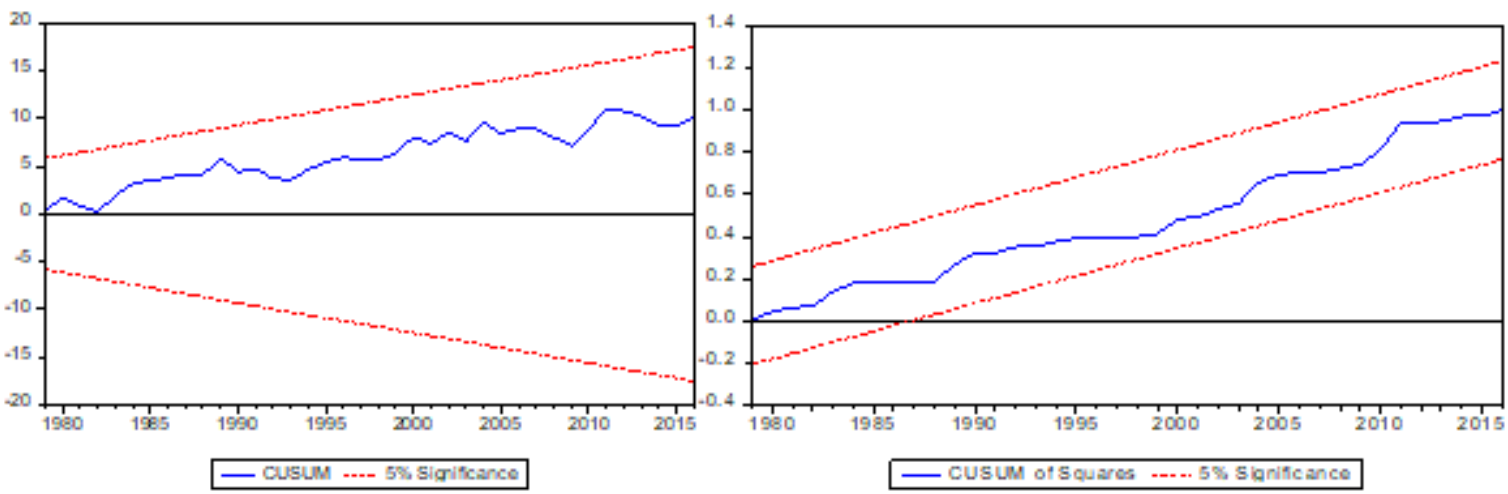

Figure 4

Stability test: COSUM AND COSUMQ 